\title{
Recurrent Submandibular Gland Acinic Cell Carcinoma
}

National Cancer Institute

\section{Source}

National Cancer Institute. Recurrent Submandibular Gland Acinic Cell Carcinoma. NCI

Thesaurus. Code C153572.

The reemergence of submandibular gland acinic cell carcinoma after a period of remission. 